Research article

\title{
Cultured Kaposi's sarcoma tumor cells exhibit a chemokine receptor repertoire that does not allow infection by HIV-I Thierry Simonart ${ }^{1}$, Claire Debussher ${ }^{1}$, Corinne Liesnard ${ }^{2}$, Laurent Debaisieux ${ }^{2}$, Marie-Luce Delforge ${ }^{2}$, Aurore de Lavareille ${ }^{3}$, Philippe Hermans ${ }^{5}$, Jean-Paul Van Vooren ${ }^{4}$ and Patrick Stordeur ${ }^{* 3}$
}

\author{
Address: ${ }^{1}$ Department of Dermatology,Erasme University Hospital,808 Route de Lennick,Brussels,1070,Belgium, ${ }^{2}$ Virology,Erasme \\ University Hospital,808 Route de Lennick,Brussels,1070,Belgium, ${ }^{3}$ Immunology,Erasme University Hospital,808 Route de \\ Lennick,Brussels,1070,Belgium, ${ }^{4}$ Internal Medicine, Erasme University Hospital,808 Route de Lennick, Brussels,1070,Belgium and \\ ${ }^{5}$ Department of Infectious Diseases, Saint-Pierre University Hospital, Brussels,100o, Belgium \\ E-mail: Thierry Simonart - tsimonar@ulb.ac.be; Claire Debussher - tsimonar@ulb.ac.be; Corinne Liesnard - cliesnar@ulb.ac.be; \\ Laurent Debaisieux - Laurent.Debaisieux@ulb.ac.be; Marie-Luce Delforge - mdelforg@ulb.ac.be; Aurore de Lavareille - adelavar@ulb.ac.be; \\ Philippe Hermans - P_Hermans@compuserve.com; Jean-Paul Van Vooren - jpvanvoo@ulb.ac.be; \\ Patrick Stordeur* - Patrick.Stordeur@ulb.ac.be \\ *Corresponding author
}

Published: 24 July 2001

Received: 2I March 200I

BMC Dermatology 2001, I:2

Accepted: 24 July 2001

This article is available from: http://www.biomedcentral.com//47/-5945/I/2

(C) 200I Simonart et al; licensee BioMed Central Ltd. Verbatim copying and redistribution of this article are permitted in any medium for any noncommercial purpose, provided this notice is preserved along with the article's original URL. For commercial use, contact info@biomedcentral.com

\begin{abstract}
Background: HIV-I is known to play a critical role in the pathogenesis of AIDS-associated Kaposi's sarcoma (KS). However, it remains controversial whether KS cells are target cells for HIV infection. The aim of this study was to investigate the expression of chemokine receptors in KS cell cultures and to determine whether these cells can be infected by HIV-I.

Material and Methods: KS-derived cells and KS-YI cells were investigated using RT-PCR for the expression of CD4, CCR3, CCR5, CCR8 and CXCR4 mRNA. HIV infectivity of these cells was determined by P24 antigen and HIV-I RNA production, as well as by HIV-I DNA integration.

Results and Discussion: With the exception of CCR8 which is expressed by KS-derived spindle cell cultures but not by KS-YI cells, unstimulated KS cells express no significant levels of CD4, CCR3, CCR5 or CXCR4 mRNA. HIV infectivity assays showed that KS cells were unpermissive to HTLVIIIB and JRFL strains. Although the expression of CXCR4 mRNA could be upregulated by interleukin-I $\beta$, stimulation of KS cells by this cytokine did not allow infection by HIV-I.

Conclusions: This shows that KS cells exhibit a chemokine receptor repertoire that does not allow infection by HIV-I. Other cell types making up KS lesions, such as inflammatory cells, are likely to represent the source of HIV-I products cooperating to promote KS development and progression.
\end{abstract}

\section{Introduction}

Kaposi's sarcoma (KS) is an angioproliferative disease that has aroused considerable interest of late, as it is one of the major tumors found in patients with the acquired immune deficiency syndrome (AIDS). It is histologically characterized by inflammation, prominent angiogenesis 
and proliferating spindle cells which are considered to be the tumor cells of KS. The pathogenesis of KS is not fully understood. The current hypothesis to explain the initiation and progression of the tumor is a multi-step pathway involving cytokine dysregulation and active infection by human herpesvirus 8 (HHV-8) [1,2,3,4]. The extremely high frequency of KS among HIV-infected patients, together with the particular aggressiveness of AIDS-KS suggests that HIV plays a critical role in KS pathogenesis [3]. Several studies point to the HIV-1 Tat protein synergizing with growth factors to promote the growth of AIDS-KS $[5,6]$. However, whether HIV can directly infect KS cells is still controversial. Delli Bovi et al. did not detect HIV DNA in KS lesions using Southern blot analysis [7] whereas an hybridization study demonstrated the presence of HIV RNA transcripts in AIDS-KS tissues within factor XIIIa dermal dendrocytes [8]. Using polymerase chain reaction (PCR), HIV-1 proviral DNA was usually not found in spindle cells derived from KS lesions of AIDS patients [9,10]. A single study found that KS-derived cells can productively be infected by HIV-1 in vitro [11]. This infection was followed by increased expression of interleukin (IL)-1 $\beta$ and IL-6, which could be relevant to the pathogenesis of AIDS-related KS, knowing the crucial role of cytokines and growth factors in the development of this tumor[1,3,5]. The question of the infectibility of KS cells by HIV-1 raises the question of the ways of attachment and entry of the virus into these cells. Although CD4+ spindle-shaped cells have been detected in AIDS-KS tissues [12], it is generally assumed that KS cells do not harbor the CD4 antigen $[9,13,14]$. However, it is noteworthy that many cell types that do not express $\mathrm{CD} 4$, like endothelial cells, are also infectible to various strains of HIV-1 [15].

Cellular entry of HIV is now known to require one of several seven-transmembrane domain G-protein-coupled receptors, principally CXCR4, an $\alpha$-chemokine receptor, and $\mathrm{CCR}_{5}$ whose natural ligands are $\beta$-chemokines $[16,17]$. CXCR-4, also named fusin, functions as a coreceptor for T-cell-tropic HIV-1 strains. On the other hand, CCR-5 is the most important coreceptor for M-tropic strains which replicate in monocyte-derived macrophages. The role of CCR3 and CCR8, which are other $\beta$-chemokine receptors, is more controversial. Interestingly, these chemokine receptors can sometimes support viral entry in the absence of CD4 $[15,18]$. Whether KS cells express these chemokine receptors and can respond to their natural chemokine ligands is so far unknown. To develop a more detailed understanding of these G-protein-coupled receptors in KS pathogenesis, we examined their expression in KS-derived spindle cell cultures and in an immortalized KS cell culture (KS-Y1). We next determined whether these cells could be infected by HIV-1.

\section{Materials and methods Reagents}

IL-1 $\beta$ and LPS were obtained from Sigma (Bornem, Belgium). SDF-1 $\alpha$ was purchased from R\&D Systems (Abingdon, UK).

\section{Cell cultures}

KS-cell cultures were derived from cutaneous KS biopsies from three patients with AIDS (KS-1, -2 and -3 ). Cell cultures were also obtained from a renal transplant recipient (KS-4) and from a patient with sporadic KS (KS5). Cultures were established similarly as previously described $[14,19]$. Briefly, fresh lesions were minced in small pieces and enzymatically digested with collagenase $(1 \mathrm{mg} / \mathrm{ml}$ ) from Clostridium histolyticum for $90 \mathrm{~min}$. Cells were grown without additional growth factors in minimum essential medium D-Val (Gibco, Paisley, Scotland) containing $10 \%$ inactivated fetal calf serum (FCS) (Gibco), 1\% glutamine, 1\% non-essential amino acids, penicillin $(100 \mathrm{U} / \mathrm{ml})$ and streptomycin $(100 \mu \mathrm{g} / \mathrm{ml})$. Cells isolated from these cultures were characterized as KS cells morphologically (spindle-shaped morphology) and immunohistochemically (positivity for laminin, vimentin, collagen IV, $\alpha$-smooth muscle actin, CD13, ICAM-1 and Bcl-2 protein, and negativity for cytokeratin, von Willebrand factor, ICAM-2, ELAM-1, VCAM-1, $\mathrm{CD}_{4}, \mathrm{CD} 34, \mathrm{CD} 40, \mathrm{CD} 45, \mathrm{CD} 68$ ) in accordance with previously published reports [14,19]. In addition, we and others have shown that these cells constitutively produce a 92-kDa type IV collagenase [20] and can traverse basement membranes $[5,21]$, which suggests they have an invasive phenotype and that they may adequately represent the tumor cells of KS. The experiments presented here were performed on cell cultures between the third and the fifteenth passage.

The KS-Y1 cell line which displays a higher proliferative activity than cutaneous-derived KS cell cultures [10] was provided by Dr. Y. Lunardi-Iskandar (Institute of $\mathrm{Hu}-$ man Virology, Baltimore, MA). It was maintained in RPMI (Gibco) containing 10\% inactivated FCS (Gibco), $1 \%$ glutamine, $1 \%$ non-essential amino acids, $1 \%$ sodium pyruvate, penicillin $(100 \mathrm{U} / \mathrm{ml})$ and streptomycin (100 $\mu \mathrm{g} / \mathrm{ml}$ ). No exogenous growth factor was added.

\section{RT-PCR for CD4, CCR3, CCR5, CCR8, CXCR4 and $\beta$ actin mRNA}

Total RNA was isolated by using a commercially available reagent (Tripure ${ }^{\mathrm{TM}}$, Roche Diagnostics, Brussels) following manufacturer's instructions. In order to avoid amplification of contaminating genomic DNA, total RNA was treated with 10 units of RQ1 RNase-free DNase (Promega Corporation, Madison, WI) for 30 minutes. DNase was then inactivated by adding $500 \mu \mathrm{l}$ of Tripure $^{\mathrm{TM}}$, and total RNA was extracted once again. Re- 
verse transcription of mRNA was carried out as follows. Eight $\mu \mathrm{l}$ of water containing $500 \mathrm{ng}$ of total RNA were added to $2 \mu \mathrm{l}$ of oligo dT primer $(0.5 \mu \mathrm{g} / \mu \mathrm{l})$, and incubated at $65^{\circ} \mathrm{C}$ for $10 \mathrm{~min}$. Samples were chilled on ice, and $10 \mu \mathrm{l}$ of RT mix containing the following components were added: 1) $4 \mu \mathrm{l} 5 \times \mathrm{RT}$ buffer (250 mM Tris $\mathrm{HCl}, \mathrm{pH}$ 8.3, $375 \mathrm{mM} \mathrm{KCl}, 15 \mathrm{mM} \mathrm{MgCl}{ }_{2}$ ); 2) $2 \mu \mathrm{l}$ deoxynucleotide triphosphate mix (10 mM each); 3) $0.2 \mu \mathrm{l} \mathrm{BSA} \mathrm{(1} \mathrm{mg/ml);}$ 4) $0.6 \mu \mathrm{l}(25 \mathrm{U})$ human placental ribonuclease inhibitor (RNAguard ${ }^{\circledR}$, Pharmacia Biotech, Uppsala, Sweden); 5) $1 \mu \mathrm{l}$ (200 U) M-MLV reverse transcriptase (Gibco); 6) 0.2 $\mu \mathrm{l} \mathrm{H}_{2} \mathrm{O}$; 7) $2 \mu \mathrm{l}$ DTT (100 mM). The samples were then incubated at $37^{\circ} \mathrm{C}$ for $60 \mathrm{~min}$.

The PCR reaction was carried out in a $25 \mu$ l final volume containing: 1) $5 \mu \mathrm{l}$ (3 $\mu \mathrm{l}$ for $\beta$ actin) cDNA; 2) $1 \mu \mathrm{l}$ sense and $1 \mu \mathrm{l}$ antisense primer (0.1 $\mu \mathrm{g} / \mu \mathrm{l}$ each); 3) $0.5 \mu \mathrm{l}$ deoxynucleotide triphosphate mix (10 mM each); 4) $2.5 \mu \mathrm{l}$ $10 \times$ PCR buffer (100 mM Tris HCl, pH 8.3, $500 \mathrm{mM} \mathrm{KCl,}$ $15 \mathrm{mM} \mathrm{MgCl}_{2}$ ); 5) $0.2 \mu \mathrm{l}$ Taq DNA polymerase (5 U/ $\left.\mu \mathrm{l}\right)$ (Roche); 6) $\mathrm{H}_{2} \mathrm{O}$ up to $25 \mu \mathrm{l}$. After an initial denaturation step at $94^{\circ} \mathrm{C}$ for $4 \mathrm{~min}$, temperature cycling was initiated for each cycle as follows: $94^{\circ} \mathrm{C}$ for $20 \mathrm{sec}, 55^{\circ} \mathrm{C}$ for $20 \mathrm{sec}$, $72^{\circ} \mathrm{C}$ for $45 \mathrm{sec} ; 35$ (30 for $\beta$ actin) cycles were performed, followed by a final elongation step at $72^{\circ} \mathrm{C}$ for 8 min. The sequences of the primers were (sense, $5^{\prime} \rightarrow 3^{\prime}$ ) CTGGGCAAAAAAGGGGATAC, AGTTTGTGCCCCCGCTGT, TGGTCCTGCCGCTGCTTG, GCCGTGTATGCCCTAAAGGT, GCCCTCCTGCTGACTATTCC, GGGTCAGAAGGATTCCTATG, and (antisense, $5^{\prime} \rightarrow 3^{\prime}$ ), GTGGGTGTCAGAGTTGGCAG, TGAAAAACACCGCCATGA, TGCTCCCCAGTGGATCGG, ATGGCCTTGGTCTTGTTGTG, ACTGTGGTCTTGAGGGCCTT, GGTCTCAAACATGATCTGGG, for CD4, CCR3, CCR5, CCR8, CXCR4 and $\beta$ actin, respectively. The PCR products were run on a $2 \%$ agarose gel, stained by ethidium bromide and then photographed on Polaroid 667-type film. The expected band size, checked against DNA molecular weight markers, was 309, 645, 430, 299, 236 and 237 base pairs for $\mathrm{CD}_{4}, \mathrm{CCR}_{3}, \mathrm{CCR} 5, \mathrm{CCR} 8, \mathrm{CXCR} 4$ and $\beta$ actin, respectively.

\section{Flow cytometric analysis}

Cell surface expression of CXCR4 and CD4 receptors was analyzed by flow cytometry. Briefly, $5 \times 10^{5}$ cells were suspended in ice-cold PBS, $0.1 \%$ bovine serum albumin. Cells were incubated on ice for $20 \mathrm{~min}$ with the primary 44717.111 (anti-CXCR4) antibody (R\&D Systems) or SK3 (anti-CD4) antibody (Becton Dickinson, San Jose, CA). Cells were then washed twice with ice-cold PBS, 0.1\% bovine serum albumin and FACS analysis was done with a FACScan flow cytometer (Becton Dickinson). Negative controls were provided by replacing the primary antibody with non-immune immunoglobulin fraction.

\section{$C a^{2}+$ mobilization assay}

For measurements of intracellular calcium $\left[\mathrm{Ca}^{2}+\right]_{\mathrm{i}}$, the cells were washed twice with HBBS without calcium and magnesium (Gibco). After washing, the cells were resuspended at $5 \times 10^{6} / \mathrm{ml}$ in HBBS and incubated for $30 \mathrm{~min}$ at $37^{\circ} \mathrm{C}$ with $250 \mu \mathrm{M}$ sulfinpyrazone (Sigma), $100 \mu \mathrm{g} / \mathrm{ml}$ Pluronic F-127 (Molecular Probes, Eugene, OR) and 7.5 $\mu \mathrm{M}$ of the fluorescent calcium probe Fluo-3AM (Molecular Probes). After incubation, the cells were washed twice with RPMI 1640 (Biowhitakker, Verviers, Belgium) supplemented with $10 \%$ FCS and $250 \mu \mathrm{M}$ sulfinpyrazone. Before analysis, all samples were placed in a $37^{\circ} \mathrm{C}$ water bath. After a 10 sec period acquisition on a FACScan flow cytometer (Becton Dickinson), SDF-1 $\alpha$ was added from concentration stocks in water.

\section{HIV-I infection assay}

KS cells were seeded at $2 \times 10^{4}$ cells per well in a volume of $1 \mathrm{ml}$ into 24-well microplates. The cells were incubated for $1 \mathrm{~d}$ to allow attachment and entry into the exponential growth phase and were then treated with IL-1 $\beta$ (50-500 $\mathrm{pg} / \mathrm{ml})$ or LPS $(0.5-5 \mu \mathrm{g} / \mathrm{ml})$. After $2 \mathrm{~d}$ incubation at $37^{\circ} \mathrm{C}$ in $5 \% \mathrm{CO}_{2}$, the cells were inoculated with the HTLVIII-B $\mathrm{T}$ cell tropic strain or the JRFL macrophage tropic strain (1000 TCID 50/ml). Phytohemagglutinin (PHA)-stimulated peripheral blood mononuclear cells (PBMCs) obtained from a healthy HIV-negative donor and inoculated with both HIV strains were used as positive control. They were cultivated in RPMI 1640 medium containing $15 \%$ FCS and IL-2 and were infected with HTLVIIIB or JRFL similarly as KS cells. Non-inoculated KS cells and PBMCs were used as negative controls. After $24 \mathrm{~h}$, virus inoculum was removed, and cells were washed 3 times with Hank's balanced salt solution to remove cell-free virus before replenishing the medium. In order to measure the inoculum background, aliquots of supernatants were removed after the last washing and the addition of fresh medium. The HIV-pulsed cell cultures were maintained for up to 3 weeks. The presence of the p24 antigen was monitored twice a week, using an enzyme immunoassay (Innotest $\mathrm{HIV} \mathrm{Ag} \mathrm{mAb,} \mathrm{Innoge-}$ netics, Ghent, Belgium). A culture was considered positive when at least $50 \mathrm{pg} / \mathrm{ml} \mathrm{p} 24$ antigen was detected and when a 4-fold increase in p24 antigen levels on 2 consecutive supernatants was observed.

To further confirm these results, similar experiments were performed for the analysis of the production of HIV-1 RNA. Briefly, KS cells were seeded at $10^{5}$ cells per well in a volume of $2.5 \mathrm{ml}$ into 6-well plates and treated as described above. The cells were then inoculated with respectively 100000,200000 , and 500000 virions $/ \mathrm{ml}$ of the HTLVIII-B strain. HTLVIII-B-inoculated PHAstimulated PBMCs were used as positive controls. Noninoculated KS cells and PBMCs were used as negative 
controls. After $2 \mathrm{~h}$, virus inoculum was removed, and cells were washed 6 times with HBBS to remove cell-free virus before replenishing the medium. Production of HIV RNA in culture supernatants was measured once a week on cell-free supernatant, using the Amplicor HIV1 Monitor test version 1.5 (Roche Diagnostics, Branchburg, NJ).

Cells were also harvested at various time points by scrapping and the presence of HIV-1 DNA was measured by semi-quantitative polymerase chain reaction (PCR), as previously described [22]. In order to definitively exclude virus DNA integration, PCR for LTR/gag region, which allows the detection of late reverse transcription product, was performed as previously described [23].

\section{Results \\ Chemokine receptor expression in KS-derived spindle cells and $K S-Y I$ cells}

The results of the PCR assays are shown in Figure 1. KS cells were examined for the presence of mRNA of CD4 and of the HIV-1 coreceptors CXCR4 and CCR 5 . The mRNA expression of CCR3 and CCR8 was also investigated. The amplified fragments of $\mathrm{CD} 4$ were revealed at very low levels in RNA from KS-derived spindle cells. There was a passage-dependent expression of these receptors, with cells at late passages exhibiting neither CD4 nor CXCR4 detectable levels. No difference could be evidenced between cells obtained from KS cells obtained from AIDS and from non-AIDS patients. With the exception of CCR8, a chemokine receptor which is selectively engaged by HHV-8-encoded vMIP-I [24], none of the other investigated chemokine receptors was expressed at significant levels in unstimulated KS-derived cells. The KS-Y1 cell line, which may be regarded as a homogenous KS cell culture [10], exhibited barely detectable levels of CD4 mRNA and none of the investigated chemokine receptor mRNA. All PCR performed, except the water controls, were positive for $\beta$-actin, showing the presence of amplifiable cDNA.

The cell surface expression of CXCR- 4 and CD 4 was then evaluated by FACS analysis by using the specific antiCXCR-4 monoclonal antibody 44717.111 and anti-CD4 monoclonal antibody $\mathrm{SK}_{3}$. This indicated that neither KS-derived spindle cells nor KS-Y1 cells exhibited significant expression of CXCR4 receptors on their surface (Fig. 2). Confirming previous studies, we also found that KS cells do not harbor the CD4 receptor on their surface (data not shown)[14].

To further determine whether KS cells were devoid of functional CXCR4 receptor, our subsequent studies used SDF-1 $\alpha$ to assess its ability to induce changes in intracellular levels of $\mathrm{Ca}^{2}+$. By contrast to $\mathrm{T}$ cells which are

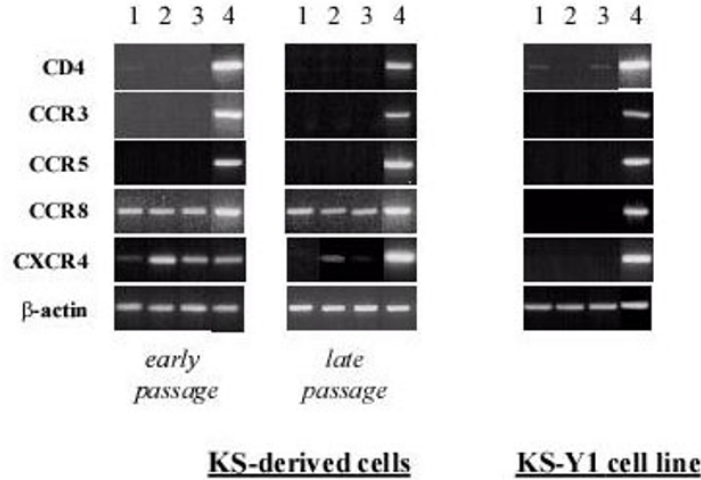

Figure I

RT-PCR for CD4, CCR3, CCR5, CCR8, CXCR4 and $\beta$ actin mRNA detection in KS cells. RT-PCR was performed on total RNA extracted from KS-2 cells at early and late passages (passages 4 and 12, respectively) and from KSYI cells, as described in the Materiel and Methods section. Lanes I, non-stimulated cells; lanes 2 and 3, cells were stimulated for 8 hours with $80 \mathrm{pg} / \mathrm{ml} \mathrm{IL-I} \beta$ (lanes 2) or 4 hours with I $\mu \mathrm{g} / \mathrm{ml}$ LPS (lanes 3); lanes 4 , positive controls for RTPCR, consisting in RT-PCR performed on total RNA extracted from $T$ cells (positive controls for CD4, CCR8, CXCR4 and $\beta$ actin), LPS-stimulated macrophages (positive control for CCR5) and $\mathrm{CHO}$ cells transfected with the CCR3 gene (positive control for CCR3). Similar results were obtained with KS-I, $-3,-4$ and -5 cells (data not shown).

known to express CXCR4 and to be responsive to its ligand, KS cells exhibited no significant elevation of $\left[\mathrm{Ca}^{2}+\right]_{\mathrm{i}}$ after treatment with SDF-1 $\alpha$ (10 -1000 $\mathrm{nM}$ ) (data not shown).

Since inflammatory cytokines regulate the transcription of several chemokine receptors [25] and are known to play a role in KS pathogenesis through autocrine and paracrine loops, we examined the effects of inflammatory mediators on $\mathrm{CCR}_{3}, \mathrm{CCR} 5, \mathrm{CCR} 8$ and CXCR4 mRNA expression in KS cells. Using commercially available ELISA kits (BioSource, Fleurus, Belgium), we found that the treatment of KS-derived cells with IL-1 $\beta$ induced a dose-dependent release of IL-6 and IL-8, indicating effective stimulation of the cells (data not shown). As shown in Fig. 1, IL-1 $\beta$ caused an increase in steady state levels of CXCR4 mRNA in KS-derived spindle cells but not in the KS-Y1 cell line. Maximal increase in CXCR4 levels was reached within $8 \mathrm{~h}$ after treatment. The IL-1 $\beta$ induced expression of CXCR4 mRNA was passage-dependent, with stimulated cells at late passages $(>10)$ expressing fewer transcripts than cells at early passages. We then investigated whether IL-1 $\beta$ could induce the expression of functional CXCR4 receptor on cell cultures at 
A

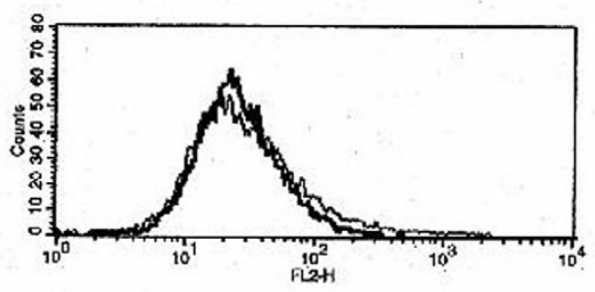

B

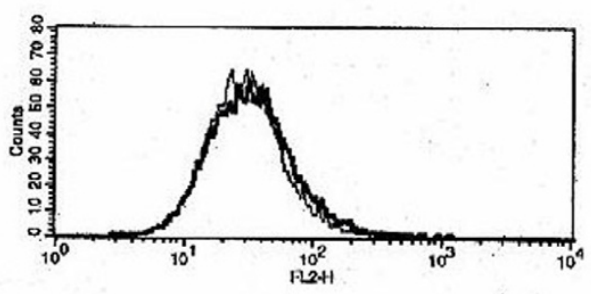

C

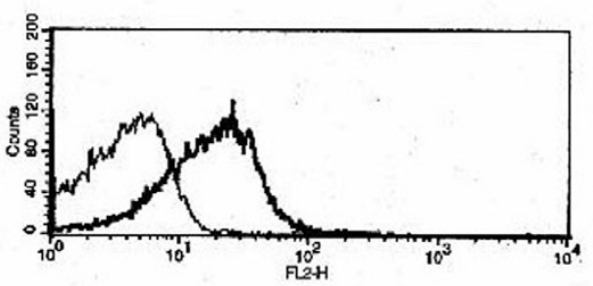

Figure 2

Flow cytometric analysis of CXCR4. (A) KS-2 cells. (B) IL-I $\beta$-stimulated KS-2 cells. (C) T cells. Thin curve, control isotype; thick curve, anti-CXCR4 antibody. Similar results were obtained with $\mathrm{KS}-\mathrm{I}$ and -5 cells (data not shown).

passage $>10$. Flow cytometry analysis revealed no significant surface expression of CXCR4 after stimulation (Fig. 2), suggesting absence of translation into surface protein expression or expression below flow cytometry sensitivity levels. Similarly, IL-1 $\beta$-stimulated KS cells exhibited no significant elevation of $\left[\mathrm{Ca}^{2}+\right]_{\mathrm{i}}$ after treatment with SDF-1 $\alpha$ (10 -1000 nM) (data not shown). No effect of IL$1 \beta$ was evidenced on the levels of $\mathrm{CD}_{4}, \mathrm{CCR}_{3}, \mathrm{CCR}_{5}$ and CCR8 mRNA. LPS achieved similar effects as IL-1 $\beta$ (Fig. 1).

\section{Sensitivity of KS-derived spindle cells and KS-YI cells to HIV-I infection}

We investigated the ability of HTLVIII-B and JRFL strains to infect KS-Y1 cells and KS spindle cells. Three independent infection attempts for each cell type indicated that HIV-1 RNA and p24 antigen production never rose above background values, even after stimulation with IL-1 $\beta$ or LPS. There was also no HIV-1 proviral DNA integration as assessed by semi-quantitative PCR DNA as well as by PCR for LTR/gag region (Fig. 3). No cytopathic effect could be detected.

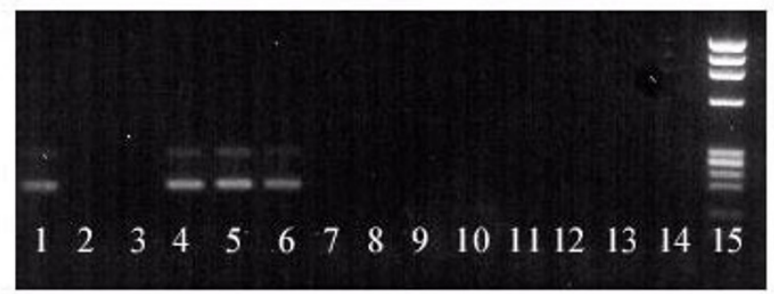

\section{Figure 3}

PCR for LTR/gag region (detection of late reverse transcription products). PCR were performed on DNA extracted from cell cultures 21 days after infection attempt. Lane I, positive control for PCR (DNA extracted from PBMC from a HIV-I-infected patient); lane 2, PCR negative control (water); lanes 3 to 6, DNA extracted from PBMC from a HIV-I-negative donor, exposed to 0, I00000, 200000 or 500000 virions respectively; lanes 7 to 10, DNA from KSY-I cells exposed to 0, 100000, 200000 or 500000 virions respectively; lanes II to I4, DNA from KS-2 cells exposed to 0, 100000, 200000 or 500000 virions respectively; lane I5, DNA molecular weight marker.

\section{Discussion}

In vitro establishment of KS-derived spindle cell cultures have allowed to show that the aggressive behavior of AIDS-associated KS may be related to HIV-1 products synergizing with growth factors to promote the growth of KS cells [3,5]. However, direct infection of KS cells by HIV-1 remains controversial. In addition to the CD4 antigen, chemokine receptors have emerged as important portals of entry for HIV-1 infection $[16,17]$. In this report, we found that KS-derived cell cultures and the KS-Y1 cell line express barely detectable levels of CD4 and CXCR4 mRNA. As there was a passage-dependent expression of these receptors, it is suggested that their expression may be related to non-KS cells co-isolated and co-cultured with KS cells during early cell culture passages. CCR8, a $\beta$-chemokine receptor whose role as HIV co-receptor remains unclear [26], was expressed by KS-derived spindle cells but not by the KS-Y1 cell line, which may stress the controversy regarding the ontogenic origin of this cell line. By contrast, neither $\mathrm{CCR}_{3}$ nor $\mathrm{CCR}_{5}$ were expressed by unstimulated KS cells. As KS is thought to be an inflammatory cytokine-mediated disease, at least in the early stage of tumor development $[1,3]$, we tested the possibility that these receptors would be expressed under conditions of immune stimulation. One of the most important inflammatory cytokine involved KS pathogenesis is IL-1ß, a pleiotropic cytokine that is synthetized during a broad variety of antigenic stimuli, including viral infections. IL-1 $\beta$ levels are known to be elevated in homosexual men with HIV-1 infection, which may, at least partly, explain the more aggressive course of KS in these individuals as compared with people with classic KS. Analogously, increased IL-1 $\beta$ levels might be in- 
volved in the reported development and/or progression of KS during opportunistic infections [1,3,27]. Here, we found that IL-1 $\beta$ induced the expression of significant CXCR4 mRNA levels in KS cells at early passages and induced its expression at low levels in KS cells at late passages. A possible explanation for this passage-dependent induction of CXCR4 mRNA expression is that the effect of IL-1 reflects effects on cell types making up KS lesions and co-isolated with KS cells. For example, IL-1 $\beta$ has been shown to modulate the transcription of CXCR4 in endothelial cells [25]. Accordingly, the KS-Y1 cell line, which may be regarded as a homogenous KS cell culture [10], did not express CXCR4 after stimulation with IL-1 $\beta$. Thus, to avoid misinterpretation with other cell types making up KS lesions [9], we investigated whether IL-1 $\beta$ could induce the expression of functional CXCR4 receptor on cell cultures at late passages. This indicated that IL-1 $\beta$ failed to induce CXCR 4 on the cell surface at significant levels, suggesting absence of translation into surface protein expression or expression below flow cytometry sensitivity levels. Absence of functional CXCR4 receptor on KS cell surface was further demonstrated by absence of intracellular calcium mobilization with the CXCR4 ligand SDF- $1 \alpha$. No effect of IL-1 $\beta$ was evidenced on the levels of $\mathrm{CD}_{4}, \mathrm{CCR}_{3}, \mathrm{CCR}_{5}$ and CCR8 mRNA.

To test the possibility that HIV-1 could infect KS cells independently of these known HIV-1 receptors and co-receptors, we performed in vitro infectivity assays. Neither KS-derived spindle cells nor KS-Y1 cells, could be productively infected by HIV-1 in vitro, as evidenced by the absence of production of HIV-1 RNA and p24 antigen as well as the absence of HIV-1 proviral DNA integration. KS-derived cells co-cultured with IL-1 $\beta$ remained unpermissive to HIV-1. As HIV is known to exert direct cytopathic effects on infected cells, the absence of receptors for viral entry may represent a mechanism that allows KS cells to escape from lysis.

\section{Conclusions}

From our data, we conclude that KS cells exhibit a chemokine receptor repertoire that does not allow infection by HIV-1. Other cell types making up KS lesions, such as inflammatory cells, are likely to represent the source of HIV-1 products cooperating to promote KS development and progression.

\section{List of abbreviations used}

KS: Kaposi's sarcoma; FCS: fetal calf serum; PHA: phytohemagglutinin; PBMC: peripheral blood mononuclear cells.

\section{Competing Interests}

Have you in the past five years received reimbursements, fees, funding, or salary from an organization that may in any way gain or lose financially from the publication of this paper? No

Do you hold any stocks or shares in an organization that may in any way gain or lose financially from the publication of this paper? No

Do you have any other financial competing interests? No

Are there any non-financial competing interests you would like to declare in relation to this paper? No

\section{Acknowledgments}

The excellent technical help from Michel Tchetcheroff, Nadine Gijbels and Marie-Hélène Jurion is gratefully acknowledged. The authors also thank $\mathrm{Dr}$ Kristel Van Laethem for providing primers specific for the LTR/gag region.

\section{References}

I. Fiorelli V, Gendelman R, Samaniego F, Markham PD, Ensoli B: Cytokines from activated $T$ cells induce normal endothelial cells to acquire the phenotypic and functional features of AIDS-Kaposi's sarcoma spindle cells. J Clin Invest 1995, 95: 17231734

2. Chang Y, Cesarman E, Pessin MS, Lee F, Culpepper J, Knowles DM, Moore PS: Identification of herpesvirus-like DNA sequences in AIDS-associated Kaposi's sarcoma. Science 1994, 266: I8651869

3. Gallo RC: The enigmas of Kaposi's sarcoma. Science 1998, 282:1837-1839

4. Murakami-Mori K, Mori S, Bonavida B: Molecular pathogenesis of AIDS-associated Kaposi's sarcoma: growth and apoptosis. Adv Cancer Res 2000, 78:159-197

5. Ensoli B, Gendelman R, Markham PD, Fiorelli V, Colombini S, Raffeld M, Cafaro A, Chang HK, Brady JN, Gallo RC: Synergy between basic fibroblast growth factor and HIV-I Tat protein in induction of Kaposi's sarcoma. Nature 1994, 37 I:674-680

6. Kelly GD, Ensoli B, Gunthel CJ, Offermann MK: Purified Tat induces inflammatory responses genes in Kaposi's sarcoma cells. AIDS 1998, I2:|753-|76|

7. Delli Bovi P, Donti E, Knowles DM, Friedman-Kien A, Luciw PA, Dina $D$, Dalla-Favera R, Basilico C: Presence of chromosomal abnormality and lack of AIDS retrovirus DNA sequences in AIDSassociated Kaposi's sarcoma. Cancer Res 1986, 46:6333-6338

8. Mahoney SE, Duvic M, Nickoloff BJ, minshall M, Smith LC, Griffiths CE, Paddock SW, Lewis DE: Human immunodeficiency virus (HIV) transcripts identified in HIV-related psoriasis and Kaposi's sarcoma lesions. J Clin Invest 1991, 88:174-185

9. Kaaya EE, Parravicini C, Ordonez C, Gendelman R, Berti E, Gallo RC, Biberfeld P: Heterogeneity of spindle cells in Kaposi's sarcoma: comparison of cells in lesions and in culture. J Acquir Immune Defic Syndr 1995, 1 0:295-305

10. Lunardi-Iskandar Y, Gill P, Lam VH, Zeman RA, Michaels F, Mann DL, Reitz MS, Kaplan M, Berneman ZN, Carter D, et al: Isolation and characterization from an immortal neoplastic cell line (KS Y-I) from AIDS-associated Kaposi's sarcoma. J Natl Cancer Inst |99|, 87:974-98|

II. Huang YQ, Li JJ, Kim KS, Nicolaides A, Zhang WG, Le J, Poiesz BJ, Friedman-Kien AE: HIV-I infection and modulation of cytokine and growth factor expression in Kaposi's sarcoma-derived cells in vitro. AIDS 1993, 7:317-322

12. Nickoloff $B$ J, Griffiths EM: The spindle-shaped cells in cutaneous Kaposi's sarcoma: histologic simulators include factor XIIla dermal dendrocytes. Am J Pathol 1989, I 35:793-800

13. Uccini S, Ruco L, Monardo F, Stoppacciaro A, Dejana E, La Parola IL, Cerimele D, Baroni CD: Co-expression of endothelial cell and macrophage antigens in Kaposi's sarcoma cells. J Pathol 1994, | 73:23-3| 
14. Simonart T, Hermans P, Schandene L, Van Vooren JP: Phenotypic characteristics of Kaposi's sarcoma tumour cells derived from patch-, plaque- and nodular-stage lesions: analysis of cell cultures isolated from AIDS and non-AIDS patients and review of the literature. Br J Dermatol 2000, I 43:557-563

15. Moses AV, Bloom FE, Pauza CD, Nelson JA: Human immunodeficiency virus infection of human brain capillary endothelial cells occurs via a CD4/galactosylceramide-independent mechanism. Proc Natl Acad Sci USA 1993, 90:10474-10478

16. Doms RW, Peiper SC: Unwelcomed guests with master keys: how HIV uses chemokine receptors for cellular entry. Virology 1997, 235:179-190

17. Feng Y, Broder CC, Kennedy PE, Berger EA: HIV-I entry cofactor, functional cDNA cloning of a seven-transmembrane, $G$ protein-coupled receptor. Science 1996, 272:872-877

18. Borsetti A, Parolin C, Ridolfi B, Sernicola L, Geraci A, Ensoli B, Titti F: CD4-independent infection of two CD4(-)/CCR5(-)/ CXCR4(+) pre-T-cell lines by human and simian immunodeficiency viruses. J Virol 2000, 74:6689-6694

19. Benelli R, Repetto L, Carlone S, Parravicini C, Albini A: Establishment and characterization of two new Kaposi's sarcoma cell cultures from an AIDS and a non-AIDS patient. Res Virol I994, 45:25I-259

20. Blankaert D, Simonart T, Van Vooren JP, Parent D, Liesnard C, Farber CM, Marique T, Werenne J: Constitutive release of metalloproteinase-9 (92-kDa type IV collagenase) by Kaposi's sarcoma cells. J Acquir Immune Defic Syndr 1998, 18:203-209

21. Simonart T, Degraef C, Mosselmans R, Hermans P, Lunardi-Iskandar Y, Noel JC, Van Vooren JP, Parent D, Heenen M, Galand P: Earlyand late-stage Kaposi's sarcoma-derived cells but not activated endothelial cells can invade de-epidermized dermis. J Invest Dermatol 200I, I I6(5):679-85

22. Vandamme AM, Fransen K, Debaisieux L, Marissens D, Sprecher S, Vaira D, Vandenbroucke AT, Verhofstede C: Standardisation of primers and an algorithm for HIV-I diagnostic PCR evaluated in patients harbouring strains of diverse geographical origin. The Belgian AIDS Reference Laboratories.J Virol Methods 1995, $51: 305-316$

23. Van Laethem K, Beuselinck K, Van Dooren S, De Clercq E, Desmyter $\mathrm{J}$, Vandamme AM: Diagnosis of human immunodeficiency virus infection by a polymerase chain reaction assay evaluated in patients harbouring stains of diverse geographical origin. J Virol Methods 1998, 70:153-156

24. Dairaghi DJ, Fan RA, McMaster BE, Hanley MR, Scahll TJ: HHV8-encoded VMIPI selectively engages chemokine receptor CCR8. Agonist and antagonist profiles of viral chemokines. J Biol Chem 1999, 274:21569-72154

25. Gupta SK, Lysko PG, Pillarisetti K, Ohlstein E, Stadel JM: Chemokine receptors in human endothelial cells. Functional expression of CXCR4 and its transcriptional regulation by inflammatory cytokines. J Biol Chem 1998, 273:4282-4287

26. Lee S, Tiffany LH, King L, Murphy PM, Golding H, Zaitseva MB: CCR8 on human thymocytes functions as a human immunodeficiency virus type I coreceptor. J Virol 2000, 74:6946-6952

27. Stürlz M, Brandstetter H, Zietz C, Eisenburg B, Raivich G, Gearing DP, Brockmeyer $\mathrm{NH}$, Hofschneider $\mathrm{PH}$ : Identification of interleukin$I$ and platelet-derived growth factor- $B$ as major mitogens for the spindle cells of Kaposi's sarcoma: a combined in vitro and in vivo analysis. Oncogene 1995, 10:2007-2016

\section{Pre-publication history}

The pre-publication history for this paper can be accessed here:

http://www.biomedcentral.com/content/backmatter/ 1471-2334-1-6-b1.pdf
Publish with BioMed Central and every scientist can read your work free of charge

"BioMedcentral will be the most significant development for disseminating the results of biomedical research in our lifetime."

Paul Nurse, Director-General, Imperial Cancer Research Fund

Publish with BMC and your research papers will be:

- available free of charge to the entire biomedical community

- peer reviewed and published immediately upon acceptance

- cited in PubMed and archived on PubMed Central

- yours - you keep the copyright

Submit your manuscript here: BioMedcentral.com

http://www.biomedcentral.com/manuscript/ 